\title{
Reproductive Performance and Mortality Rate in Local and Dorper $\times$ Local Crossbred Sheep Following Controlled Breeding in Ethiopia
}

\author{
Mesfin Lakew $^{1 *}$, Mussie Haile-Melekot ${ }^{2}$, Getinet Mekuriaw ${ }^{2}$, Solomon Abreha3 ${ }^{3}$, \\ Haimanot Setotaw ${ }^{3}$ \\ ${ }^{1}$ Sirinka Agricultural Research Center, Woldia, Ethiopia \\ ${ }^{2}$ College of Agriculture and Environmental Sciences, Bahir Dar University, Bahir Dar, Ethiopia \\ ${ }^{3}$ College of Agriculture, Wollo University, Dessie, Ethiopia \\ Email: ${ }^{*}$ meslamess@gmail.com
}

Received 25 July 2014; revised 10 September 2014; accepted 25 September 2014

Copyright (C) 2014 by authors and Scientific Research Publishing Inc.

This work is licensed under the Creative Commons Attribution International License (CC BY).

http://creativecommons.org/licenses/by/4.0/

(c) (i) Open Access

\section{Abstract}

The reproductive and lamb mortality data $(n=187)$ of the Local and crosses of Dorper $\times$ Local ewes following natural controlled breeding in Ethiopia were analysed. Data were collected during 2009-2011 at Sirinka breeding, evaluation and distribution site, eastern Amhara region of Ethiopia. Breed, lamb sex, birth season, birth year, birth type and ewes' parity were considered as fixed effects. Data analyses were performed using general linear model procedures. Breed was a significant source of variation: the local sheep attained faster the age at first lambing than the crossbred ewe lambs ( $469 \pm 8.45$ vs. $555 \pm 6.25$ days, $p<0.0001)$, whereas the crossbred ewes weighed more than the local sheep ewes at the age of first lambing $(32.7 \pm 0.63 \mathrm{vs} .22 .8 \pm 0.43 \mathrm{~kg}, \mathrm{p}<$ 0.0001). Birth year had also important influence on the age and weight at first lambing of ewes. Ewes showed better performance during the later study years, differences attributed due to the improved management advantages in later years. The crossbred and local ewes were comparable in their litter size, despite the fact that the lambing interval of crossbred ewes was longer than the local ewes ( $306 \pm 4.62$ vs. $287 \pm 2.38$ days). Additionally, there was no significant difference in mortality rate between the two breeds. This study confirms that the local ewes had higher annual reproductive rate than that of the crossbred sheep ewes $(1.49 \pm 0.02 \mathrm{vs} .1 .37 \pm 0.01$ lambs $)$ under the same environmental conditions. The present results suggested that better management and breeding program probably will increase the productivity of the local sheep.

\footnotetext{
${ }^{*}$ Corresponding author.

How to cite this paper: Lakew, M., Haile-Melekot, M., Mekuriaw, G., Abreha, S. and Setotaw, H. (2014) Reproductive Performance and Mortality Rate in Local and Dorper $\times$ Local Crossbred Sheep Following Controlled Breeding in Ethiopia. Open Journal of Animal Sciences, 4, 278-284. http://dx.doi.org/10.4236/ojas.2014.45035
} 


\section{Keywords}

\section{Reproduction, Controlled Breeding, Mortality, Dorper $\times$ Local, Local Sheep, Sirinka}

\section{Introduction}

In Ethiopia, farmers rear sheep mainly for sale and consumption. Sheep owners gain a vast range of products and services such as meat, milk, skin, wool, manure, gifts, religious rituals, etc. [1]. Sheep are also a means of risk mitigation during crop failures, property security and monetary saving in addition to many other socioeconomic and cultural functions [2]. Sheep contributes $21 \%$ of the total ruminant livestock meat output of the country, with the annual national mutton production estimated to be at 77 thousand metric tons [3].

While contributing significantly to meat production of the country, productivity or output of per sheep is low [4]. Thus, the productivity of indigenous sheep has to be improved and efficient sheep genetic improvement programs must be initiated to boost output and profitability of the producers [5]. To improve sheep productivity, therefore, crossbreeding with exotic breeds is considered as the most rapid way of improving productivity of indigenous sheep breeds [6].

To accomplish the crossbreeding program, the Ethiopian Sheep and Goat Productivity Improvement Program (ESGPIP) took the responsibility for importation of improved genotypes, multiplication of purebreds, crossing with indigenous sheep and distribution of both crossbred and pure exotic animals to sheep producers. To carry out the activities, four nucleus and ten Breeding, Evaluation and Distribution (BED) sites were established in different regions of the country. The program begun using Dorper sheep breed for crossbreeding purposes. In Amhara National Regional State the program has established its activity, at Sirinka Agricultural Research Center (SARC) BED site to cross the local sheep with Dorper sheep; and the center has distributed 50\% Dorper crossbred sires to sheep producers of the area.

Therefore, to utilize this newly introduced genotype effectively, it is necessary to evaluate their reproductive and survival performance under local conditions. This study reports the reproductive performance and mortality rate of the local sheep and their cross with Dorper following natural controlled breeding under on station conditions in eastern Amhara region.

\section{Materials and Methods}

\subsection{Description of the Study Area}

Reproductive records $(n=187)$ collected from 2009 to 2011 at the breeding program aimed to improve the productivity of the local sheep via crossbreeding at SARC, BED site were analysed in this study. Sirinka Agricultural Research Center, sheep breeding, evaluation and distribution (BED) site is located in eastern Amhara region of Ethiopia $\left(11^{\circ} 45^{\prime} 00^{\prime \prime} \mathrm{N}, 3^{\circ} 36^{\prime} 36^{\prime \prime} \mathrm{E}\right.$ about $508 \mathrm{~km}$ north east of Addis Ababa at an altitude of 1850 m.a.s.l.). The mean annual rainfall was recorded as $950 \mathrm{~mm}$ over the data collection period. The rainfall pattern is bimodal, where the main rainy season occurs from June to September and the short rainy season from February to April is erratic. The mean maximum and minimum temperature of the area are $26^{\circ} \mathrm{C}$ and $13^{\circ} \mathrm{C}$, respectively.

\subsection{Study Animals}

The local sheep kept at the station locally is named "Tumelie", and the community of the study area believe that the local sheep was a cross between Wollo and Afar sheep populations. Gizaw [7] classified the Tumelie sheep population as Afar sheep breed, but Lemma [8] groups it in the rift valley sheep. According to Lemma [8], the local sheep is characterized by a well-developed fat-tail curved upward at the tip, small size, short and coarse hair and homogenous in their colour and commonly plain white, light-brown and red, polled, straight head and short ears.

Dorper sheep was developed from a Dorset Horn ram and a Blackhead Persian ewe in the harsh dry regions of South Africa [9]. This large body sized and a meat type sheep is known as a hardy adaptable breed suited to harsh environments [10]. Dorper became renowned for the following out-standing breed qualities: hardiness, adaptability, good mothering, high fertility, sexual virility, good carcass and attractive physical appearance [11]. 


\subsection{Flock Management}

Following natural controlled breeding, ewes were mated with pure Dorper rams to produce $1 / 2$ Dorper $\times 1 / 2$ local lambs. Ewes were mated in single sire groups of at least 30 ewes for one ram. At mating ewes were herded with their respective sire groups during the day time and depart for the night time to be housed together.

Irregularly, concentrate supplementation was provided based on their age group and physiological status. During the long dry season, lactating ewes and rams were supplemented with $400 \mathrm{~g}$ /day of concentrate and nonlactating ewes supplemented with $200 \mathrm{~g}$ /day of concentrate. Lambs were kept with their dams until weaning (three months of age). After weaning lambs grazed in separate sex groups and were offered $100 \mathrm{~g} /$ day of concentrate for one month after weaning and during the dry season.

All animals were dewormed using albendazole and tetramizole in the months of June, September and March to reduce worm burden. Moreover, breeding ewes and lambs were also dipped for ticks and mites with Diazinon $60 \%$. All animals on the station were vaccinated for Peste des Petits Ruminants (PPR), Pasteurellosis, Anthrax and sheep pox. Sick animals were attended to and the date and cause of sickness were recorded.

\subsection{Data Management and Analysis}

Data were analyzed using the General Linear Models procedure of SAS [12]. Least squares analyses of variance were used to evaluate the effect of breed (two levels: Local and Dorper $\times$ Local), lamb sex (two levels: male and female), birth season (two levels: dry and wet), ewes' parity (three levels: 1, 2 and 3), birth type (two levels: single and multiple) and birth year (three levels: 2009, 2010 and 2011). The effect of season of lambing was defined as dry (January to June) and wet (July to December). Age at first lambing (AFL) was computed by the difference in days between the birth date and first lambing date of ewes. Lambing interval (LI) was computed by the difference in days between two successive lambing for all ewes with more than one lambing records. Annual reproductive rate (ARR), which is the number of lambs weaned per ewe per year, was calculated for each individual ewe using the formula suggested by Ibrahim [13]: ARR = S $(1-\mathrm{M}) / \mathrm{I}$; Where $\mathrm{S}$ is litter size, $\mathrm{M}$ is the rate of lamb pre-weaning mortality and I is lambing interval in ewe in years. Mortality rates (two levels: 0,1 ) being defined as binomial traits, determined by either a lamb survived or not survived to weaning.

In the preliminary analysis the two-way interactions were not significant, and therefore, excluded from the final model. Means of the significant main factors were compared using Tukey-Kramer test. The statistical models used were

Model 1: For age or weight at first lambing

$Y_{i j}=\mu+B_{i}+Y_{j}+e_{i j}$

where: $Y_{i j}=$ the observation on age or weight at first lambing

$\mu=$ Overall mean

$B_{i}=$ Fixed effect of breed $(i=$ Local, Dorper $\times$ Local $)$

$Y_{j}=$ Fixed effect of lambing year $(j=2009,2010,2011)$

$e_{i j}=$ Effect of random error

Model 2: For lambing interval (LI), litter size (LS), annual reproductive rate (ARR) and mortality rate:

$Y_{i j k l m}=\mu+B_{i}+G_{j}+P_{k}+S_{l}+T_{m}+e_{i j k l m}$

where: $Y_{i j k l m}=$ the observation on LI, LS and ARR

$\mu=$ Overall mean

$B_{i}=$ Fixed effect of breed $(i=$ Local, Dorper $\times$ Local $)$

$G_{j}=$ Fixed effect of lamb sex $(j=$ male, female)

$P_{k}=$ Fixed effect of ewes parity $(k=1,2,3)$

$S_{l}=$ Fixed effect of lambing season $(l=$ dry, wet $)$

$T_{m}=$ Fixed effect of birth type ( $m=$ single, multiple)

$e_{i j k l m}=$ Effect of random error

Notice: the fixed effect birth type was not used for LS and ARR.

\section{Results and Discussion}

\subsection{Age and Weight at First Lambing}

The overall mean for the age at first lambing was $543 \pm 5.49$ (Table 1) and there was a significant $(p<0.0001)$ difference between the local and crossbred sheep. The local sheep were faster than the crossbred sheep ewes to 
attain the age at first lambing (469 \pm 8.45 vs. $555 \pm 6.25$ days). This finding is in agreement with Gizaw [14] who reported similar results for the indigenous sheep and their crosses with Awassi. The result obtained for the local sheep ewes was comparable to Washera sheep about $464 \pm 14.0$ days [15]. Based on several literature results while the age at first laming of the local sheep ewes found longer than $410 \pm 6.7$ days of Farta sheep [16], $410 \pm 72$ days of Gumuz sheep [17] and $404 \pm 65.4$ days of the local sheep found in the western part of Ethiopia [18], whereas shorter than 662 and 669 days of the local sheep found in the high lands of Ethiopia and their crosses with Awassi sheep, respectively [19]. These literature evidences signifies that the local sheep and Dorper crossbred ewes were found faster to attain the age at first lambing, which directly determines rate of genetic progress and population turnover rate.

The local sheep ewes found faster than the crossbred lamb ewes to attain the age at first lambing. Year of birth had also influence on the age at first lambing. The variation between years reflects the availability of feed supply and the feeding management options in the station. The present results showed that ewes had better performance during the later study years, these differences attributed due to the improved management opportunity at these periods. This is in agreement with Gbangboche et al. [20] who reported significant effect of year of birth on the age at first lambing.

The crossbred ewes were found weighed more than the local sheep ewes at the age of first lambing (32.7 \pm 0.63 vs. $22.8 \pm 0.43 \mathrm{~kg}$ ). The heavier weight observed for the crossbreds could be the genetic effects (Table 1 ). The result obtained for the local sheep was comparable to Washera sheep [15] [16]. Year of birth had also influence on the weight at first lambing. The feeding management variation between lambing years attributed to the ewes to gain condition differently (Table 1).

\subsection{Lambing Interval}

Results from the general linear model analysis of lambing interval are presented in Table 2. The lambing interval of the crossbreds (306 \pm 4.62 days) was longer than the local sheep (287 \pm 2.38 days). This finding is in agreement with Gizaw and Getachew [19] who reported longer lambing interval for Awassi crossbred sheep than the local sheep. The result obtained for the local sheep were comparable to Washera (293 \pm 17.1 days) and Farta (284 \pm 13.7 days) sheep [16], while longer than $199 \pm 33.9$ days of Gumuz sheep [17]. The variation between the study animals could be associated to ewes mating system in the breeding station, where ewes were maintained under controlled mating system that could have influence on estimating of ewes lambing interval.

Ewes lambed during the wet season (281 \pm 2.01 days) had shorter lambing interval than those ewes lambed in dry season (312 \pm 2.84 days). In agreement with this result, literatures reported similar effects of lambing season on the ewes lambing interval [15] [16]. These variations could be related to the availability of nutrition during gestation period, parturition and lactation as this affecting ewes recovery (weight gain and improvement in body condition) to come to heat early [16]. Gbangboche et al. [20] also explained the variations between estimates re-

Table 1. Least square means ( \pm S.E.) for the effects of breed and year on the age or weight at first lambing in Local and Dorper $\times$ Local sheep.

\begin{tabular}{ccccc}
\hline Effects & $\mathrm{N}$ & Age at first lambing (days) & $\mathrm{N}$ & Weight at first lambing (kg) \\
\hline Overall & 86 & $543 \pm 5.49$ & 86 & $29.7 \pm 0.56$ \\
CV (\%) & 86 & 6.35 & 86 & 12.1 \\
Breed & & $* * * *$ & $32.7 \pm 0.63^{\mathrm{a}}$ \\
Crosses & 53 & $555 \pm 6.25^{\mathrm{a}}$ & 53 & $22.8 \pm 0.43^{\mathrm{b}}$ \\
Local & 33 & $469 \pm 8.45^{\mathrm{b}}$ & 33 & $30.0 \pm 0.80^{\mathrm{a}}$ \\
Birth year & & $560 \pm 8.02^{\mathrm{a}}$ & 52 & $25.1 \pm 1.08^{\mathrm{b}}$ \\
2009 & 52 & $518 \pm 5.31^{\mathrm{b}}$ & 20 & $28.1 \pm 0.73^{\mathrm{a}}$ \\
\hline
\end{tabular}

Means with different superscript letters (a, b, c) within a trait in a column are statistically different at indicated $p$-value; ${ }^{* * *} p<0.001 ;{ }^{* * * *} p<0.0001 ; \mathrm{N}$ : Number of observations. 
Table 2. Least square means ( \pm S.E.) for the effects of breed, season, parity, lamb sex and birth type on the components of reproductive performance and mortality rate in Local and Dorper $\times$ Local sheep.

\begin{tabular}{|c|c|c|c|c|c|c|c|c|}
\hline Effects & $\mathrm{N}$ & Lambing interval & $\mathrm{N}$ & Litter size & $\mathrm{N}$ & Annual reproductive rate & $\mathrm{N}$ & Mortality rate \\
\hline Overall & 187 & $293 \pm 2.29$ & 167 & $1.04 \pm 0.01$ & 167 & $1.29 \pm 0.02$ & 167 & $6.31 \pm 0.01$ \\
\hline CV (\%) & 187 & 5.71 & 167 & 14.74 & 167 & 13.65 & 167 & 25.10 \\
\hline Breed & & ${ }^{* *}$ & & Ns & & Ns & & Ns \\
\hline Crosses & 12 & $306 \pm 4.62^{\mathrm{a}}$ & 9 & $1.17 \pm 0.00$ & 9 & $1.37 \pm 0.01$ & 9 & $6.59 \pm 0.02$ \\
\hline Local & 175 & $287 \pm 2.38^{\mathrm{b}}$ & 158 & $1.18 \pm 0.02$ & 158 & $1.49 \pm 0.02$ & 158 & $4.55 \pm 0.03$ \\
\hline Birth season & & $* * * *$ & & Ns & & $* * * *$ & & * \\
\hline Dry & 133 & $312 \pm 2.84^{\mathrm{a}}$ & 120 & $1.15 \pm 0.02$ & 120 & $1.33 \pm 0.02^{\mathrm{b}}$ & 120 & $7.58 \pm 0.02^{\mathrm{a}}$ \\
\hline Wet & 54 & $281 \pm 2.01^{\mathrm{b}}$ & 47 & $1.20 \pm 0.03$ & 47 & $1.52 \pm 0.03^{\mathrm{a}}$ & 47 & $3.85 \pm 0.02^{\mathrm{b}}$ \\
\hline Parity & & $* * * *$ & & Ns & & $* * * *$ & & ** \\
\hline 1 & 66 & $330 \pm 3.77^{\mathrm{a}}$ & 59 & $1.17 \pm 0.02$ & 59 & $1.30 \pm 0.03^{b}$ & 59 & $9.48 \pm 0.03^{\mathrm{a}}$ \\
\hline 2 & 62 & $282 \pm 1.47^{\mathrm{b}}$ & 59 & $1.20 \pm 0.03$ & 59 & $1.51 \pm 0.04^{\mathrm{a}}$ & 59 & $4.55 \pm 0.03^{b}$ \\
\hline 3 & 59 & $277 \pm 1.68^{\mathrm{b}}$ & 49 & $1.15 \pm 0.00$ & 49 & $1.47 \pm 0.01^{\mathrm{a}}$ & 49 & $3.28 \pm 0.02^{b}$ \\
\hline Lamb sex & & Ns & & Ns & & Ns & & Ns \\
\hline Female & 92 & $295 \pm 3.45$ & 81 & $1.01 \pm 0.01$ & 81 & $1.25 \pm 0.02$ & 81 & $7.53 \pm 0.02$ \\
\hline Male & 95 & $291 \pm 3.05$ & 86 & $1.06 \pm 0.02$ & 86 & $1.33 \pm 0.03$ & 86 & $5.13 \pm 0.02$ \\
\hline Birth type & & Ns & & & & & & ** \\
\hline Single & 169 & $292 \pm 5.05$ & & & & & 138 & $5.45 \pm 0.01^{b}$ \\
\hline Multiple & 18 & $304 \pm 2.47$ & & & & & 29 & $11.11 \pm 0.05^{\mathrm{a}}$ \\
\hline
\end{tabular}

Means with different superscript letters (a, b) within a trait in a column are statistically different at indicated $p$-value; ${ }^{*} p<0.01 ;{ }^{* *} p<0.001 ;{ }^{* * * *} p<$ 0.0001 ; N: Number of observations; Ns: Non-significant $(p>0.05)$.

flects the effect of different management practices, nutrition, lactation, control of reproduction management and level of genetic makeup on possibilities to prompt re-conception after lambing.

Ewes had longest lambing interval on their first parity (330 \pm 3.77 days), however at third and above parity ewes lambed with shortest interval (277 \pm 1.68 days). Similar observation was reported for Washera sheep [15]. The longer lambing interval for young ewes suggests that young ewes take longer to regain condition after lambing [13].

\subsection{Litter Size}

The least squares mean of litter size of the local sheep and their crosses with Dorper were $1.18 \pm 0.02$ and $1.17 \pm$ 0.00 , respectively (Table 2). This result revealed that the local sheep and Dorper crossbred ewes were comparable for their twining ability. The litter size of the local sheep was comparable to Washera sheep $(1.19+0.02)$ [15]. Corresponding value recorded by Mekuriaw [16] was $1.11 \pm 0.02$ to Washera sheep. Comparable estimates were also included in literatures to Horo sheep [21], Menz sheep [22] and Gumuz sheep [17]. Contrary to many literatures, in this study none of the fixed effects had influence $(p>0.05)$ on litter size of the local sheep and Dorper crossbreds. Unlike to this result, literatures were reported the effects of breed, season and parity on litter size [16] [22].

\subsection{Annual Reproductive Rate}

The local ewes had higher annual reproductive rate than that of the crossbred sheep ewes (1.49 \pm 0.02 vs. $1.37 \pm$ 0.01 lambs). The estimates of the local sheep were comparable with Washera (1.38 \pm 0.06$)$ and Farta (1.29 \pm 
0.08) sheep [16], whereas much lower than the estimates of local sheep (1.82 \pm 0.44$)$ found in the south-western part of the country [18].

Ewes lambed during the wet season had higher $(p<0.0001)$ ARR than those ewes lambed in the dry season (Table 2) probably due to green feed availability in the wet season. This is in line with Mekuriaw [16] who explained the effect of season with regard to the fluctuation of feed availability between seasons.

Ewes in the second parity had higher ARR than those ewes in first parity and later parities. Virtually, ewes in their middle parity may attain their physiological maturity, that contribute to have shorter LI and higher ARR than ewes in their early and older ages which are not able to produce to their production capacity [18]. The same author also explained briefly the effects of parity as the young ewes in their first parity are accommodating their own growth and reproduction for replacement and they are not in their mature status that has contributed to reveal longer subsequent lambing intervals and lower ARR. Different to the present results literatures revealed the non-significant effect of parity on ARR [16].

\subsection{Mortality Rate}

The overall mean for mortality rate was $6.31 \pm 0.01$ (Table 2 ) and there was not significant $(p>0.05)$ difference between the local and crossbred sheep ( $4.55 \pm 0.03$ versus $6.59 \pm 0.02$, respectively). Mortality rate was higher for lambs born in the dry season, compared to those born in the wet season. Ewes' parity $(p<0.001)$ significantly affected the mortality rate in lambs. The trend observed was a decrease in mortality rate from the first to the third ewes' parity. Similar to the effect of breed, sex difference had no significant $(p>0.05)$ effect in lambs mortality. Lambs birth type $(p<0.001)$ had also influenced lambs mortality significantly.

The mortality rate recorded in the local and crossbred sheep was found comparable. This result agrees with the results of Mekuriaw [16] who found a non significant effect of breed on lamb mortality. The increase in mortality rate in the dry season is probably due to the shortage of green feed for the ewes that gave birth in the dry season. Under such conditions ewes are hardly able to produce enough milk for their lambs. Berhan and van Arendonk [22] and Tibbo [4] reported similar seasonal trends for Menz and Horro sheep. The decrease in mortality rate with the increase in ewes' parity indicates that good mothering ability of older ewes compared with maiden ewes [23]. The high loss of lambs born from first parity ewes during the pre-weaning growth period also reflect the lower milk producing ability of first parity ewes. The effect of sex on mortality rate of the lambs was found not significant. This result support the finding of Mekuriaw [16] who reported lamb sex had no significant effect on lamb survival rate. Contrary to the present results Awgichew [23] and Tibbo [4] revealed a significant effect of lamb sex on the survival rate of Horo and Menz sheep lambs. Single born lambs had better survival rate than multiples ( $5.45 \pm 0.01$ vs. $11.11 \pm 0.05, p<0.001$ ). The effect of birth type is consistent with results of other studies that single born lambs had better survival rate as compared with lambs born multiple [4] [15] [16] [23].

\section{Conclusion}

It is concluded that the local sheep are faster to attain the age at first lambing and have shorter lambing interval than the crossbred ewes. Moreover, the local sheep had higher reproductive rate, while litter size and mortality rate were comparable for both breeds. However, the crossbreds are heavier at first lambing than the local sheep. The results indicate that under on station where conditions are favourable, productivity of the local sheep can be increased through management and breeding program. Although, these results provides a basic information for the things that need to be considered under station conditions, for a better evaluation of these breeds of sheep, it is recommended to do further study of their performance under farmers' management conditions.

\section{Acknowledgements}

We thank staff of Sirinka agricultural research center, livestock research directorate particularly to Mekonen Shibeshi, Ali Hassen, Desalegn Aychew and Solomon Tiruneh for their immense contribution during data collection. The financial support of the Amhara Regional Agricultural Research Institute is also acknowledged.

\section{References}

[1] Hirpa, A. and Abebe, G. (2008) Economic Significance of Sheep and Goats. In: Yami, A. and Merkel, R.C., Eds., Sheep and Goat Production Handbook for Ethiopia, Branna Printing Enterprise, Addis Ababa, 2-24. 
[2] Gatenby, R.M. (2002) Sheep. Macmillan Education, London.

[3] Sebsibe, A. (2008) Sheep and Goat Meat Characteristics and Quality. In: Yami, A. and Merkel, R.C., Eds., Sheep and Goat Production Handbook for Ethiopia, Branna Printing Enterprise, Addis Ababa, 325-340.

[4] Tibbo, M. (2006) Productivity and Health of Indigenous Sheep Breeds and Crossbreds in the Central Ethiopian Highlands. Ph.D. Thesis, Swedish University of Agricultural Sciences, Uppsala.

[5] Kosgey, I.S. and Okeyo, A.M. (2007) Genetic Improvement of Small Ruminants in Low-Input, Smallholder Production Systems: Technical and Infrastructural Issues. Small Ruminant Research, 70, 76-88. http://dx.doi.org/10.1016/j.smallrumres.2007.01.007

[6] Hassen, Y., Sölkner, J. and Fuerst-Waltl, B. (2004) Body Weight of Awassi and Indigenous Ethiopian Sheep and Their Crosses. Small Ruminant Research, 55, 51-56. http://dx.doi.org/10.1016/j.smallrumres.2004.01.008

[7] Gizaw, S. (2008) Sheep Resources of Ethiopia: Genetic Diversity and Breeding Strategy. Ph.D. Thesis, Wageningen University, Wageningen.

[8] Lemma, S. (2009) Phenotypic Classification and Description of Indigenous Sheep Types in Amhara National Regional State of Ethiopia. M.Sc. Thesis, Haramaya University, Dire Dawa.

[9] Richard, K. (2010) Dorper Sheep and the Production of Lean Lamb in Arid Australia. International Specialised Skills Institute, Melbourne.

[10] Schoeman, S.J. (2000) A Comparative Assessment of Dorper Sheep in Different Production Environments and Systems. Small Ruminant Research, 36, 137-146. http://dx.doi.org/10.1016/S0921-4488(99)00157-1

[11] Olivier, J.J., Marais, P.G. and Cloete, J.A.N. (1984) Evaluation of Different Breed Crosses in the Development of a White Wooled Mutton Sheep: The Afrino. South African Journal of Animal Science, 14, 105-109. http://eurekamag.com/research/005/397/005397696.php

[12] SAS (Statistical Analysis System) (2003) Ver.9.1. SAS Institute Inc., Cary.

[13] Ibrahim, H. (1998) Small Ruminant Production Techniques. ILRI Manual 3. ILRI (International Livestock Research Institute), Nairobi.

[14] Gizaw, S. (2002) Genetic Evaluation of Menz and Awassi x Menz Crossbred Sheep in Ethiopia. M.Sc. Thesis, National Dairy Research Institute, Karnal.

[15] Taye, M., Abebe, G., Lemma, S., Gizaw, S., Mekoya, A. and Tibbo, M. (2011) Reproductive Performances and Survival of Washera Sheep under Traditional Management Systems at Yilmanadensa and Quarit Districts of the Amhara National Regional State, Ethiopia. Journal of Animal Science and Veterinary Advances, 10, 1158-1165.

[16] Mekuriaw, S. (2011) Performance Evaluation of Washera, Farta and Their Crossbred Sheep in Western Highlands of Amhara Region, Ethiopia. M.Sc. Thesis, Bahir Dar University, Bahir Dar.

[17] Abegaz, S. (2007) In-Situ Characterization of Gumuz Sheep under Farmers’ Management in North-Western Lowlands of Amhara Region. M.Sc. Thesis, Haramaya University, Dire Dawa.

[18] Belay, B. and Haile, A. (2009) Reproductive Performance of Traditionally Managed Sheep in the Southwestern Part of Ethiopia. Livestock Research for Rural Development, 21. http://www.Irrd.org/Irrd21/9/bela21154.htm

[19] Gizaw, S. and Getachew, T. (2009) The Awassi x Menz Sheep Crossbreeding Project in Ethiopia: Achievements, Challenges and Lessons Learned. Proceedings of the Mid-Term Conference of the Ethiopian Sheep and Goat Productivity Improvement Program (ESGPIP), Hawassa, 13-14 March 2009, 53-62.

[20] Gbangboche, A.B., Adamou-Ndiaye, A.K.I., Youssao, M., Farnir, F., Detilleux, J., Abiola, F.A. and Leroy, P.L. (2006) Non-Genetic Factors Affecting the Reproduction Performance, Lamb Growth and Productivity Indices of Djallonke Sheep. Small Ruminant Research, 64, 133-142. http://dx.doi.org/10.1016/j.smallrumres.2005.04.006

[21] Abegaz, S., Duguma, G., Nigussie, E., Gelmesa, U., Terefe, F. and Rege, J.E.O. (2002) Factors Affecting Reproductive Performance and Estimates of Genetic Parameters of Litter Size in Horro Sheep. Journal of Agricultural Science, 139, 79-85. http://dx.doi.org/10.1017/S0021859602002265

[22] Berhan, A. and Van Arendonk, J. (2006) Reproductive Performance and Mortality Rate in Menz and Horro Sheep Following Controlled Breeding in Ethiopia. Small Ruminant Research, 63, 297-303. http://dx.doi.org/10.1016/j.smallrumres.2005.03.003

[23] Awgichew, K. (2000) Comparative Performance Evaluation of Horro and Menz Sheep of Ethiopia under Grazing and Intensive Feeding Condition. Ph.D. Dissertation, Humboldt University, Berlin. 
Scientific Research Publishing (SCIRP) is one of the largest Open Access journal publishers. It is currently publishing more than 200 open access, online, peer-reviewed journals covering a wide range of academic disciplines. SCIRP serves the worldwide academic communities and contributes to the progress and application of science with its publication.

Other selected journals from SCIRP are listed as below. Submit your manuscript to us via either submit@scirp.org or Online Submission Portal.
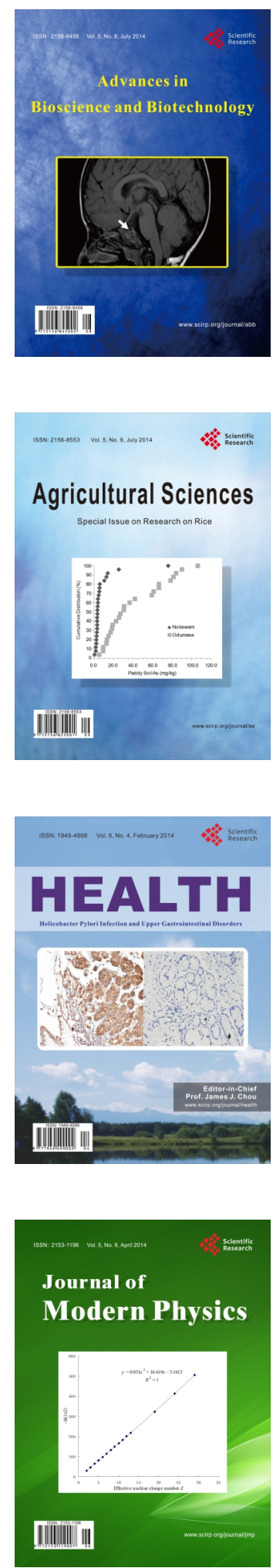
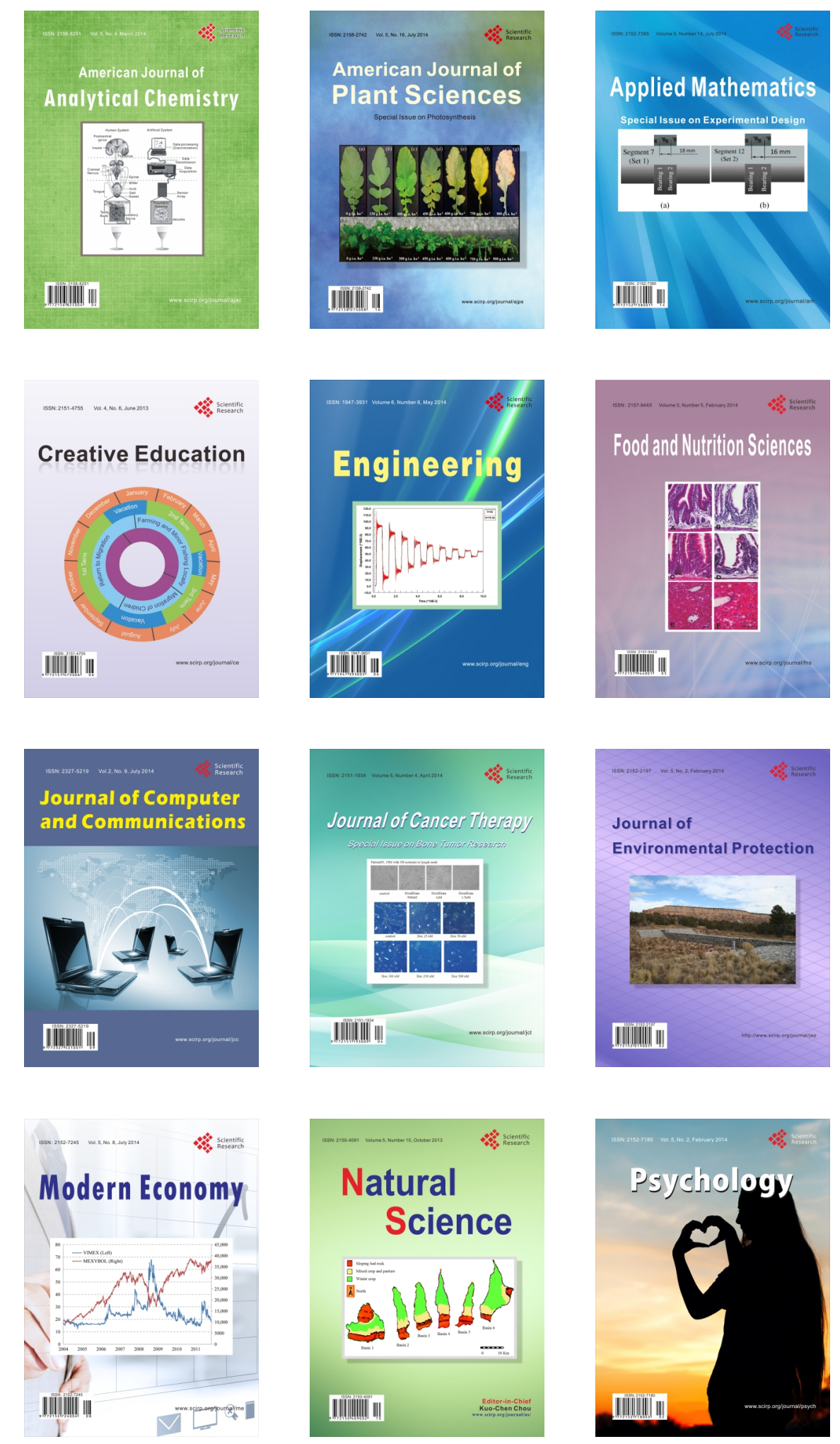